Available online:

http://journal.imla.or.id/index.php/arabi

IMLA

Arabi : Journal of Arabic Studies, 5 (1), 2020, 79-90

DOI: http://dx.doi.org/10.24865/ajas.v5i1.93

\title{
PEMANFAATAN TEKNOLOGI INFORMASI DAN KOMUNIKASI DALAM PEMBELAJARAN BAHASA ARAB DI MADRASAH ALIYAH KABUPATEN SUKOHARJO
}

\author{
Imam Makruf \\ Institut Agama Islam Negeri Surakarta, Indonesia \\ E-mail : imam.makruf@iain-surakarta.ac.id
}

\begin{abstract}
This study aimed to analyze various ICT-based media and learning resources used in learning Arabic, the selection or development process, the process of using it in learning, and the learning outcomes. Research data collected from observations, documentation, and interviews were validated with FGD and analyzed with interactive models. The results of this study show that; (1) the most widely used media in learning Arabic is powerpoint presentations with LCD and language laboratories, then video, audio and games, (2) the process of selecting developing media and learning resources is done by design and by utilization, (3) the process of utilizing media and learning resources is done more for the delivery of material at the core activities in addition to enrichment and assignment, and (4) media and learning resources for Arabic-based ICT that use material from native speakers have a positive impact on improving the motivation, self confidence, and Arabic competence of students.
\end{abstract}

Keywords: learning media, learning resources, Arabic learning, ICT

\section{Abstrak}

Penelitian ini bertujuan untuk menganalisis berbagai media dan sumber belajar berbasis TIK yang digunakan dalam pembelajaran bahasa Arab, proses pemilihan atau pengembangannya, proses pemanfaatannya dalam pembelajaran, serta hasil pembelajarannya. Data penelitian berupa hasil observasi, dokumentasi, dan wawancara yang divalidasi dengan FGD dan dianalisis dengan interactive model. Hasil analisis menunjukkan bahwa; (1) media yang paling banyak digunakan dalam pembelajaran bahasa Arab adalah presentasi powerpoint dengan LCD dan laboratorium bahasa, kemudian video, audio, dan game, (2) proses pemilihan/pengembangan media dan sumber belajar dilakukan by design dan by utilization, (3) proses pemanfaatan media dan sumber belajar lebih banyak dilakukan untuk penyampaian materi pada kegiatan inti, di samping untuk pengayaan dan penugasan, dan (4) media dan sumber belajar bahasa Arab berbasis TIK yang memperbanyak tayangan dari penutur asli memiliki pengaruh lebih baik terhadap peningkatan motivasi, kepercayaan diri, dan kompetensi berbahasa Arab para peserta didik.

Kata Kunci: media belajar, sumber belajar, pembelajaran bahasa Arab, TIK 


\section{Arabi : Journal of Arabic Studies}

\section{Pendahuluan}

Bahasa Arab merupakan salah satu bahasa internasional yang saat ini semakin diminati masyarakat. Hal ini dapat dilihat dari perkembangan pendidikan dan pembelajaran bahasa Arab yang semakin banyak diterapkan tidak hanya di sekolah atau madrasah formal, tetapi juga di berbagai lembaga kursus atau pelatihan, dan bahkan di SMA Negeri. Salah satu contoh menarik terjadi di SMAN se-kota Malang (Wardhani, 2010), meskipun minat untuk belajar bahasa Arab dari para siswa masih tergolong rendah dibandingkan dengan belajar bahasa asing lainnya seperti: bahasa Inggris, bahasa Jerman, dan Mandarin.

Di wilayah Surakarta secara umum juga ditemukan beberapa lembaga pendidikan/kursus yang mengajarkan bahasa Arab. Di Pare Kediri, yang terkenal dengan kampung Inggrisnya, sekarang juga mengembangkan materi kursusnya dengan bahasa Arab (semacam kampung Arab). Model Pare tersebut, saat ini juga mulai dikembangkan di kampung Pakel, dekat pondok pesantren Isy Karima di Karanganyar. Pada tanggal 20 Desember 2017, Desa Pakel telah secara resmi ditetapkan sebagai desa wisata bahasa Arab oleh Sekda Kabupaten Karanganyar (http://isykarima.com, 2017).

Meskipun fenomena pembelajaran bahasa Arab semakin menarik dan meluas, tetapi pada lembaga pendidikan formal seperti madrasah, masih belum juga menunjukkan keberhasilan yang signifikan. Banyak faktor yang menjadi penyebab kurang menonjolnya prestasi belajar bahasa Arab di madrasah. Di antaranya adalah faktor penggunaan media dan sumber belajar yang kurang menarik, kurang mengikuti perkembangan teknologi, atau kurang memberikan kemudahan akses kepada para peserta didik (Albantani \& Madkur, 2019). Menurut Azhar Arsyad (2003), dengan mengutip pendapat beberapa pakar seperti Gerlach \& Ely (1971), media secara garis besar adalah manusia, materi, atau kejadian yang membangun kondisi yang membuat peserta didik mampu memperoleh pengetahuan, ketrampilan atau sikap. Sementara itu, AECT (Association of Education and Communication Technology, 1977) menyatakan bahwa media adalah segala bentuk dan saluran yang digunakan untuk menyampaikan pesan atau informasi. Sedangkan Heinich dkk (2005) mendefinisikan media sebagai perantara yang mengantarkan informasi antara sumber dan penerima.

Dalam hal ini, sebenarnya saat ini sudah sangat banyak ditemukan media dan sumber belajar berbasis TIK yang dapat dengan mudah diakses dan dimanfaatkan secara gratis. Sebagai contoh, jika dicoba mencari pada mesin search engine seperti google, dengan kata kunci "belajar bahasa Arab on-line gratis", akan dengan mudah ditemukan sekitar 2.660.000 hasil. Sementara itu media dan sumber belajar berbasis TIK sebenarnya juga tidak harus dikembangkan berbasis on-line, misalnya menggunakan software seperti PowerPoint, Macromedia, dan lain-lain. Artinya, masih banyak pilihan dalam penggunaan media dan sumber belajar berbasis TIK tersebut dalam berbagai bentuknya baik on-line maupun off-line. Hal ini tentu saja bergantung pada keterampilan guru bahasa Arab dalam bidang teknologi.

Dalam mengembangkan desain pembelajaran berbasis TIK, Heinich, dkk (2005) merumuskan ASSURE Model yang berisi 6 langkah pengembangan, yaitu; (1) analyze learners, (2) state objectives, (3) select methods, media, and materials, (4) utilize media and material, (5) require learner participation, dan (6) evaluate and revise. Pada prinsipnya, semakin nyata dan melibatkan banyak indera dalam pembelajaran, sebuah media dan sumber belajar akan dapat memberikan hasil yang lebih efektif. Perbandingan pemerolehan hasil belajar melalui indera pandang dan indera dengar sangat menonjol perbedaannya. Kurang lebih 90\% hasil belajar seseorang diperoleh melalui indera pandang, dan hanya sekitar 5\% diperoleh melalui indera dengar, dan 5\% lagi dengan indera lainnya. Sementara itu Dale memperkirakan bahwa pemerolehan hasil belajar melalui indera pandang berkisar 75\%, melalui indera dengar sekitar 13\%, dan melalui indera lainnya sekitar 12\% (Arsyad, 2003).

Teknologi informasi mencakup enam bagian, yaitu; 1) teknologi masukan (input technology), 2) teknologi keluaran (output technology), 3) teknologi perangkat lunak (software 
technology), 4) technologi penyimpan (storage technology), 5) teknologi komunikasi (communication technology), dan 6) mesin pemroses (processing mechine) atau CPU (Munir, 2008).

Beberapa hasil penelitian berikut menunjukkan bahwa pembelajaran berbasis TIK lebih efektif dalam mencapai tujuan pembelajaran. Di antaranya adalah; penelitian dengan judul "Penerapan Model Pembelajaran Blended E-learning dalam Proses Perkuliahan" (Nuraini, 2009) menunjukkan hasil bahwa kegiatan perkuliahan dengan model Blended E-learning memberikan dampak positif yang cukup besar terhadap berbagai aspek kehidupan mahasiswa, dari segi keterampilan hingga segi kepercayaan diri. Penelitian dengan judul "Efektivitas Model Pembelajaran E-learning dalam Meningkatan Kualitas Hasil Belajar Insya (Menulis)" (Elis Saleha, 2008) menunjukkan hasil bahwa model pembelajaran ini sangat efektif digunakan pada mata kuliah insya. Penelitian lain dengan judul "Model E-learning untuk Pembelajaran Insya' (menulis karangan) Pada Program Pendidikan Bahasa Arab" (Sya'bani, 2008) menunjukkan hasil bahwa model pembelajaran insya dengan e-learning dapat dikembangkan dengan program Moodle yang dikembangkan dengan empat tahapan yaitu tahap analisis, perencanaan, pelaksanaan, dan evaluasi.

Selain itu, penelitian dengan judul "Pembelajaran Bahasa Arab dengan On-line Self Access Learning" (Suwito, 2009) menunjukkan hasil bahwa; salah satu cara untuk memumbuhkan semangat belajar salah satunya adalah belajar dengan cara sendiri (own style). Situs-situs yang interaktif dan fun dapat menjadi solusi berkaitan dengan pemompaan semangat peserta belajar di samping dapat secara trial and error di program software yang ditawarkan tanpa harus menanggung beban psikologis malu. Penelitian dengan judul "Pembelajaran Bahasa Arab berbasis Teknologi Informasi dan Komunikasi di Kota Padang” (Ritonga, dkk, 2016), menunjukkan hasil bahwa; model pembelajaran bahasa Arab berbasis TIK yang disebut dengan model al-hāsūb alittishāli yang dirancang termasuk dalam kategori baik. Dalam model ini semua materi dan perangkat pembelajaran dikembangkan berbasis computer. Dalam hal ini guru berfungsi sebagai motivator dan mediator pada materi-materi yang memerlukan penjelasan di kalangan peserta didik. Kemudian hasil riset Banditvilai (2016) tentang penerapan blended learning untuk meningkatkan skill berbahasa di Thailand, menunjukkan hasil bahwa praktik keterampilan berbahasa secara on-line sama baiknya dengan praktik secara langsung dan memotivasi peserta didik.

Dengan perkembangan teknologi yang sudah begitu pesatnya, beserta fasilitas yang semakin murah, mudah, dan fleksibel, maka sudah menjadi keniscayaan bagi para guru untuk memanfaatkan atau bahkan mengembangkan sendiri berbagai media dan sumber belajar berbasis TIK guna meningkatkan mutu pembelajarannya. Dalam konteks Madrasah Aliyah di Kabupaten Sukoharjo saat ini, setidaknya dapat diklasifikasi menjadi 3 (tiga) kategori, yaitu: Madrasah Aliyah Negeri (MAN Sukoharjo), Madrasah Aliyah Swasta berbasis Pondok Pesantren Modern (MA As-Salam Pabelan dan MA Al-Mukmin Ngruki), dan Madrasah Aliyah swasta biasa (MA Muhammadiyah Bekonang). Masing-masing MA tersebut memiliki kekhasan sesuai dengan karakteristik lembaganya. Meskipun demikian secara umum keberadaan media dan sumber belajar berbasis TIK lebih lengkap dimiliki oleh MA swasta berbasis pondok pesantren, disusul kemudian MAN dan MA swasta non-pesantren. Dari ketiga kategori MA tersebut, jika dilihat dari prestasinya dalam bidang bahasa Arab, misalnya dari berbagai lomba atau kejuaraan di bidang bahasa Arab, MA berbasis pondok pesantren masih lebih unggul dibandingkan lainnya.

Berdasarkan kajian hasil penelitian di atas, dan melihat kondisi nyata di lapangan yang ada, ternyata belum ada Madrasah Aliyah di Kabupaten Sukoharjo yang menerapkan pembelajaran berbasis TIK yang didesain secara khusus baik yang bersifat individual maupun interaktif on-line dan dengan serius digunakan. Madrasah Aliyah umumnya masih menggunakan media yang bersifat user, atau menggunakan software yang ada tanpa mendesain secara khusus. Di samping media, madrasah juga menggunakan berbagai sumber belajar berbasis TIK seperti bahan video dan referensi dalam bentuk pdf. Faktanya, bahwa pembelajaran di beberapa madrasah tersebut dapat 


\section{Arabi : Journal of Arabic Studies}

dikategorikan berhasil dan efektif. Untuk itulah penelitian ini berupaya untuk menganalisis kondisi riil dan problematika pembelajaran bahasa Arab dengan memanfaatkan media dan sumber belajar berbasis TIK.

Hal yang baru dari penelitian ini dibandingkan riset sejenis adalah dalam menemukan pemanfaatan media dan sumber belajar berbasis TIK yang lebih efektif untuk mengoptimalkan kemampuan berbahasa Arab peserta didik di madrasah. Dengan demikian, hasil penelitian ini diharapkan dapat dijadikan pijakan dalam pengambilan kebijakan dan pengembangan mutu pembelajaran bahasa Arab di madrasah.

\section{Metode}

Penelitian ini menggunakan pendekatan penelitian deskriptif kualitatif. Penelitian ini dilaksanakan di Madrasah Aliyah di Kabupaten Sukoharjo yaitu sebanyak 5 (lima) Madrasah Aliyah, yaitu: (1) MAN Sukoharjo, (2) MA Al-Ukhuwah Sukoharjo, (3) MA Al-Mukmin Ngruki Grogol, (4) MA As-Salam Pabelan Kartasura, dan (5) MA Muhammadiyah Bekonang. Data dikumpulkan melalui teknik observasi, wawancara, dan studi dokumentasi. Untuk pemeriksaan keabsahan atau validasi data digunakan teknik kecukupan referensial, teknik trianggulasi metode, dan didalami dengan Focus Group Discussion (FGD). Setelah data terkumpul, kemudian data tersebut dikaji secara lebih mendalam menggunakan model interaktif dari Miles \& Huberman dalam Sugiyono (2017) yang terdiri atas pengumpulan data mentah, display data, reduksi data, dan verifikasi/kesimpulan.

\section{Diagram 1. Prosedur penelitian}

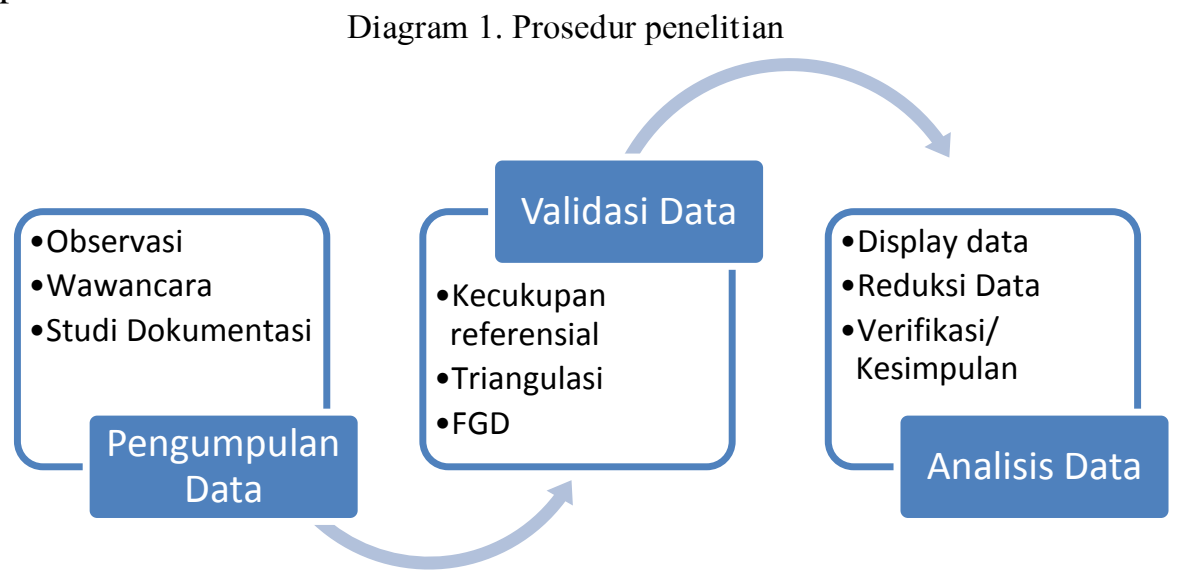

\section{Hasil Penelitian dan Pembahasan}

Dalam deskripsi data penelitian ini, secara garis besar terdapat 3 (tiga) karakteristik lembaga yang diteliti. Pertama lembaga berkarakter nageri, kedua lembaga pendidikan swasta berbasis pondok pesantren, dan ketiga adalah lembaga pendidikan swasta non-pondok pesantren. Madrasah Aliyah Negeri (MAN Sukoharjo) memiliki karakter sebagaimana lembaga negeri pada umumnya. Mulai dari kurikulum, proses pembelajaran, kualifikasi pengajar, sarana prasarana dan lain-lain. Madrasah Aliyah swasta yang berbasis Pondok Pesantren di Sukoharjo di antaranya MA AsSalam, MA Al-Mukmin, dan MA Al-Ukhuwah. Sedangkan Madrasah Aliyah swasta yang tidak berbasis pondok Pesantren adalah MA Muhammadiyah Bekonang. Dengan demikian, karakteristik masing-masing madrasah dapat dikategorisasi juga menjadi tiga kategori. Untuk yang berbasis pondok pesantren, kebetulan memiliki model pondok pesantren yang relatif sama, sehingga mereka juga relatif sama dalam hal penyelenggaraan pembelajaran bahasa Arab. Dalam hal ini, sama-sama memiliki ciri sebagai pondok pesantren modern yang memberikan penekanan pada penguatan bahasa Arab kepada para santri/siswanya. Meskipun demikian, sebenarnya PP As-Salam dan PP Al-Mukmin yang lebih identik karena sama-sama sudah mapan, sudah lama berdiri, dan sudah memiliki berbagai prestasi. Sedangkan untuk PP Al-Ukhuwah relatif masih baru, sehingga masih banyak melakukan pengembangan. Kesamaannya adalah sama-sama mewajibkan siswanya untuk tinggal di pondok pesantren, memiliki program takhasshus bahasa Arab dan juga program tahfidz 
al-Qur'an. Ketiga pondok pesantren tersebut juga menerapkan bi'ah lughawiyah dengan menggunakan bahasa Arab dalam komunikasi pembelajaran di kelas maupun di asrama.

Pembelajaran bahasa Arab di MA Al-Mukmin Ngruki menggunakan pendekatan nazhriyat al-furū' dengan tharîqah mubâsyirah. Hal ini dapat dilihat dari dokumen kurikulumnya bahwa materi bahasa Arab diajarkan dengan berbagai cabangnya, seperti Nahwu, Sharaf, Insyā, Balāghah, Tarjamah, Khat, Imlä', Tamrināt, dan Mahfüdzhāt (Dokumen Kurikulum MA AlMukmin, 2016). Sementara itu materi keislaman juga diajarkan dengan bahasa pengantar bahasa Arab. Dengan demikian, dapat dikatakan bahwa pembelajaran bahasa Arab tidak hanya diajarkan oleh guru-guru Mata Pelajaran bahasa Arab, tetapi juga didukung oleh para guru Mata Pelajaran Keislaman, dan para ustadz yang ada di asrama santri.

Proses pembelajaran di kelas, yang digunakan guru pada umumnya adalah thariqah mubāsyirah, yaitu mengajarkan bahasa Arab secara langsung dengan bahasa pengantar bahasa Arab. Sedangkan untuk strategi dan teknik-teknik pembelajaran yang digunakan bervariasi tergantung pada materi yang diajarkan, seperti: ceramah, tanya jawab, praktik, diskusi, penugasan, dan lainnya. Proses pembelajaran dilakukan secara klasikal pada jam formal, sedangkan yang di luar kelas dilaksanakan di luar jam formal. Saat ini sedang diprogramkan untuk menghadirkan native speaker dari Yaman, tetapi masih proses dan belum terlaksana. Fokusnya adalah untuk memperkuat kompetensi para ustadz dalam bidang komunikasi lisan.

Dalam hal penggunaan media pembelajaran bahasa Arab berbasis TIK, umumnya mereka menggunakan media LCD dengan presentasi PowerPoint. Di samping itu juga penggunaan laboratorium bahasa dan pemanfaatan media audio-visual seperti film, khithabah, dan bahan-bahan lain yang digunakan dalam memperkaya penguasaan bahasa peserta didik. Ketersediaan jaringan internet di pondok pesantren ini juga memberikan peluang pada guru untuk menggunakan bahanbahan on-line dalam pembelajaran. Meskipun demikian, pemanfaatan internet masih belum optimal.

Kondisi yang hampir serupa juga terjadi di MA Al-Ukhuwah. Dalam video profil dari MA Al-Ukhuwah dijelaskan oleh ustadz Agus Suseno bahwa program pembelajaran bahasa Arab menjadi program yang sangat diperhatikan, bahkan pada tahun pertama siswa mendapatkan pembekalan bahasa Arab secara intensif. Kemudian untuk pengembangan bahasa Arab digunakan sebagai bahasa pengantar dalam pembelajaran di kelas baik pada mata pelajaran bahasa Arab maupun pada mata pelajaran lainnya. Untuk itu maka para guru yang mengajar direkrut dari perguruan tinggi yang memiliki latar belakang bahasa Arab yang kuat, terutama dari lulusan Timur Tengah (http://ma.alukhuwah.com, diakses 8 Agust us 2017).

Model pembinaan bahasa Arab sebagaimana di MA Al-Ukhuwah tersebut juga dilakukan pada pondok pesantren modern yang lain. Dengan demikian, kebijakan dan program pembelajaran yang dilaksanakan sudah dapat dikatakan sangat baik dan efektif. Untuk implementasi dari kebijakan program pembelajaran berbahasa Arab ini maka semua guru di Madrasah Aliyah tersebut disyaratkan untuk dapat berbahasa Arab aktif. Kecuali untuk mata pelajaran nonkeislaman yang diberikan toleransi untuk tidak menggunakan bahasa Arab, misalnya mata pelajaran Matematika, Bahasa Inggris, Fisika, dan lain-lain yang merupakan Mata Pelajaran umum.

Dalam pelaksanaan pembelajaran bahasa Arab di kelas, guru bahasa Arab menggunakan media pembelajaran berbasis TIK seperti LCD dan audio visual di laboratorium. Meskipun demikian dalam pemakaian media tidak mesti dilakukan setiap pertemuan, tetapi disesuaikan dengan kebutuhan dan kesesuaian dengan kompetensi atau skill yang akan dilatihkan pada peserta didik. Dari semua media yang digunakan, PowerPoint masih merupakan media yang paling banyak digunakan. Baik dalam pengembangannya dibuat sendiri oleh guru maupun dimodifikasi dari bahan-bahan yang sudah ada. Dalam hal ini guru lebih banyak menggunakan bahan-bahan yang sudah ada dan dipilih yang lebih sesuai dengan kebutuhan pembelajaran. Madrasah ini juga sudah memanfaatkan jaringan internet untuk mendukung proses pembelajaran, khususnya dalam mencari 


\section{Arabi : Journal of Arabic Studies}

bahan-bahan referensi atau sumber belajar dan bahan media pembelajaran. Meskipun demikian belum dikembangkan dengan model e-learning.

Proses pembelajaran bahasa Arab di MA As-Salam juga tidak jauh berbeda dengan pondok pesantren lainnya. Hal ini dapat dilihat dari kurikulum yang dikembangkan dan program pembelajaran yang dilaksanakan. "Kurikulum MA PPMI Assalaam pada tingkat awal menekankan pada Ulüm Syar'iyah (Al-Qur'an dan Ulumul Qur'an, Hadits dan Ulumul Hadits, Fiqih dan Ushul Fiqih, Aqidah Akhlak, SKI) serta kompetensi berbahasa Arab dan Inggris". (http://assalaam.or.id/pendidikan-formal/ma-5/, diakses 8 Agustus 2017). Di samping itu, MA AsSalam juga mendapatkan mu'ädalah dari Universitas Al-Azhar Kairo Mesir. Hal ini menunjukkan adanya standarisasi pembelajaran yang sudah memadai, yang salah satunya adalah kompetensi bahasa Arab yang dikembangkan di madrasah tersebut.

Terkait dengan pemanfaatan media dan sumber belajar bahasa Arab, dari tiga responden yang diwawancarai, semua menyatakan menggunakan media dan sumber belajar berbasis TIK. Meskipun demikian intensitas penggunaannya tidak semua sering menggunakannya. Sedangkan bentuk media atau sumber belajar yang digunakan antara lain laptop (netbook), LCD projector, internet, bahan presentasi PowerPoint, e-book, dan media audio. Para responden menyatakan alasan penggunaan media dan sumber belajar tersebut, antara lain praktis, efisien waktu, lebih menarik perhatian siswa, pembelajaran tidak monoton, dan mempermudah dalam penjelasan materi (Wawancara, 14 Agustus 2017).

Penggunaan media dan sumber belajar berbasis TIK pada umumnya merupakan media yang dibuat sendiri oleh guru bahasa Arab. Hal ini sebagaimana dinyatakan para responden. Meskipun demikian, proses pembuatan atau pengembangan bahan ajar tersebut tidak semuanya dibuat sendiri dalam arti dirancang dan didesain dari awal sampai dengan pembuatannya secara menyeluruh oleh guru bahasa Arab. Proses pembuatan umumnya menggunakan bahan-bahan yang sudah ada yang diperoleh dari internet, atau dari sumber lainnya, kemudian dikembangkan dan dimodifikasi sesuai kebutuhan pembelajaran. Bahan-bahan yang umumnya tidak dikembangkan sendiri seperti gambar atau video yang diambil dari internet. Sementara untuk bahan presentasi dengan PowerPoint umumnya dibuat sendiri dengan disisipi audio, video, atau gambar-gambar yang diambil dari internet atau e-book (Wawancara, 14 Agustus 2017).

Pembelajaran bahasa Arab di MA Muhammadiyah Bekonang Mojolaban Sukoharjo dilaksanakan lebih banyak di kelas. Pembelajaran dilaksanakan dengan berbagai strategi dengan memanfaatkan media pembelajaran yang cukup bervariasi. Salah satu media berbasis TIK yang digunakan guru adalah PowerPoint yang dipresentasikan dengan LCD. Media ini digunakan dalam menyampaikan materi, memberikan stimulus pada peserta didik, dan memberikan contoh-contoh penerapan bahasa Arab dalam bentuk video dan lain-lain.

Media PowerPoint dikembangkan oleh guru pengampu dengan mengambil bahan-bahan yang sudah tersedia baik secara on-line maupun off-line. Dalam pemanfaatannya, guru menggunakan media untuk kebutuhan yang bervariasi. Meskipun demikian, salah satu tujuan utamanya adalah agar membuat peserta didik lebih tertarik dan termotivasi dalam mengikuti pembelajaran bahasa Arab. Untuk pengembangan media tersebut, terdapat kendala yang di antaranya adalah keterbatasan kemampuan guru dalam bidang pengembangan media terutama yang berupa desain grafis, animasi, dan video pembelajaran. Dengan demikian, kebanyakan materi berupa teks, gambar atau kadang juga ada tambahan sisipan video.

Pembelajaran bahasa Arab di MAN Sukoharjo dilaksanakan dengan berbagai strategi dan media pembelajaran berbasis TIK. Orientasi pembelajaran bahasa Arab di MAN ini sesuai dengan kurikulum 2013 yang ditetapkan oleh Kementerian Agama RI. Berbeda dengan pembelajaran bahasa Arab yang dilaksanakan di madrasah berbasis pondok pesantren, pembelajaran bahasa Arab di madrasah ini cenderung masih belum optimal. Hal ini antara lain disebabkan karena keterbatasan jam pelajaran, tidak adanya program asrama untuk semua siswa, dan tidak adanya 
dukungan dari guru mata pelajaran lain yang mengajar dengan menggunakan pengantar bahasa Arab.

Menurut Ibu Khoiriyah Umuri, guru bahasa Arab di MAN Sukoharjo, proses pemanfaatan media pembelajaran berbasis TIK yang paling banyak menggunakan PowerPoint dengan LCD di kelas. Bahan-bahan yang dikembangkan menjadi bahan presentasi dengan PowerPoint sebagian dikembangkan sendiri oleh guru dalam bentuk text dipadukan dengan animasi. Misalnya untuk menunjukkan perubahan fi'il mädhi ke mudhori', dan sebagainya, dengan cara pemberian animasi dan warna pada huruf mudhära'ah-nya (FGD, 19 Agustus 2017). Hal ini juga diperkuat oleh pernyataan Bapak Kusun Dahari selaku Wakamad bidang Kurikulum, bahwa ketersediaan sarana dan media berbasis TIK seperti LCD dan Laboratorium memang masih terbatas, sehingga LCD yang ada masih bersifat mobile dan harus dibawa dari kantor ketika guru mau menggunakan (FGD, 19 Agustus 2017).

Pemanfaatan media pembelajaran bahasa Arab yang digunakan bapak Galih Ismail (wawancara, 4 Agustus 2017) juga tidak jauh berbeda. Menurutnya, beliau menggunakan speaker aktif dan LCD dalam pembelajaran, meskipun itu tidak sering dilakukan. Menurut Bapak Galih, pemanfaatan media audio di dalam proses pembelajaran biasanya digunakan untuk memperdengarkan teks lisan atau materi istimä.'. Sedangkan media LCD biasanya digunakan untuk memberikan pengayaan dan menampilkan gambar terkait dengan mufrodat yang disampaikan (wawancara, 4 Agust us 2017). Hal ini hampir sama yang disampaikan Ibu Khoiriyah Umuri, bahan-bahan yang sudah ada secara on-line saat ini umumnya lebih tepat untuk pembelajaran usia ibtidaiyah dan kurang cocok untuk usia Madrasah Aliyah (FGD, 19 Agustus 2017).

Dari data-data yang telah terkumpul tersebut, maka dapat dibahas secara rinci dari beberapa aspek berikut ini.

\section{Media dan Sumber Belajar Berbasis TIK yang Digunakan}

Dalam penelitian ini data dikumpulkan menggunakan teknik observasi wawancana, dan dokumentasi. Di samping itu, data divalidasi dan diperkaya melalui FGD dengan para responden. Berikut ini disajikan temuan-temuan data yang dikumpulkan dengan berbagai teknik tersebut.

Berdasarkan hasil observasi dan wawancara, diperoleh data bahwa media pembelajaran yang paling banyak digunakan dalam pembelajaran bahasa Arab di Madrasah Aliyah baik negeri maupun swasta di Kabupaten Sukoharjo adalah LCD dan komputer/laptop. Pembelajaran bahasa Arab memanfaatkan LCD untuk menayangkan berbagai materi pembelajaran yang sudah didesain menjadi bahan presentasi. Di samping bahan presentasi yang umumnya menggunakan Microsoft PowerPoint, juga digunakan berbagai bahan audio visual seperti: film, animasi, dan rekamanrekaman kegiatan berbahasa Arab.

Media lain yang digunakan dalam pembelajaran bahasa Arab adalah laboratorium bahasa. Keberadaan laboratorium bahasa tersebut tampaknya sudah menjadi bagian yang tidak terpisahkan dari penyelenggaraan madrasah. Laboratorium bahasa ini pula yang digunakan dalam pembelajaran bahasa Arab untuk membantu guru dalam menyampaikan materi pembelajaran bahasa khususnya pada materi istimā' dan kaläm.

Sumber belajar yang digunakan dalam pembelajaran bahasa Arab cukup beragam. Dari berbagai sumber belajar yang digunakan, semua madrasah memanfaatkan buku materi pelajaran sebagai sumber belajar utama. Di samping itu kemudian didukung dengan keberadaan sumbersumber bacaan yang bersifat on-line atau digital, siaran televisi berbahasa Arab dan berbagai media massa cetak berbahasa Arab. Temuan ini jika merujuk pendapatnya Michael Lesk, telah memanfaatkan digital library. Menurutnya, digital Library is a collection of information which is both digitized and organized (Lesk, dalam Munir, 2008). Fungsi digital library dapat dilihat dari tiga sudut pandang, yaitu: dari tujuan rancangannya, fungsi dalam proses belajar, dan layanan yang disediakan. 


\section{Arabi : Journal of Arabic Studies}

Merujuk pada pendapat Edgar Dale yang dikenal dengan Kerucut Pengalaman (Arsyad 2003), bahwa semakin konkret sebuah pengalaman belajar, akan semakin baik dan semakin besar tingkat keberhasilannya. Oleh karena itu, dalam pembelajaran keterampilan berbahasa Arab, tentu saja praktik langsung akan menjadi pengalaman belajar yang paling baik, di samping juga mudah dan praktis dalam pelaksanaannya. Kemudian terkait dengan pemanfaatan media audio visual seperti LCD yang memungkinkan untuk itu, akan memberikan tingkat capaian pembelajaran lebih besar, yaitu sekitar 75\% untuk media visual, dan 13\% untuk audio. Dengan demikian, jika keduanya dipadukan akan memberikan capaian pembelajaran yang lebih besar lagi.

Jika dilihat dari intensitas penggunaannya, maka penggunaan LCD untuk presentasi dengan PowerPoint merupakan media yang paling sering digunakan dibandingkan media lainnya. Hal ini disebabkan karena materi yang dapat dikembangkan dengan PowerPoint lebih banyak dan lebih mudah dibandingkan dengan media lainnya. Di samping itu, keberadaan bahan-bahan dengan powerpoint lebih mudah didapatkan.

Pemanfaatan media dan sumber belajar sebenarnya tidak dapat dipisahkan dengan upaya untuk meningkatkan aktivitas belajar dari peserta didik. Dengan demikian, hal ini sangat terkait dengan strategi yang dikembangkan dalam pembelajaran. Jika melihat pada hasil riset dari bin Samah, R., dkk (2016), tentang efektivitas metode dalam pembelajaran bahasa Arab, direkomendasikan penggunaan tiga metode pembelajaran yang dinilai efektif, yaitu: gathering, enhancing, and applying. Ketiga metode tersebut sangat memungkinkan dikembangkan dengan menggunakan berbagai media dan sumber belajar berbasis TIK.

\section{Proses Pemilihan/Pengembangan Media dan Sumber Belajar Berbasis TIK}

Dari berbagai media dan sumber belajar bahasa Arab yang digunakan di Madrasah Aliyah, pada umumnya hanya media presentasi PowerPoint yang dibuat sendiri oleh guru bahasa Arab. Sedangkan media yang lain pada umumnya dipilih dari berbagai sumber dan bahan yang ada kemudian tinggal memanfaatkan dalam proses pembelajaran. Materi yang dibuat sendiri oleh guru umumnya berupa presentasi teks yang dipadukan dengan gambar dan animasi sederhana. Sedangkan untuk media yang membutuhkan desain grafis dan multimedia umumnya diambil dari bahan-bahan yang sudah ada dengan sebagian diberikan modifikasi.

Dalam teori media pembelajaran, proses pemanfaatan media dikenal adanya media pembelajaran yang "by design", dan ada pula yang "by utilization". Dalam hal ini, proses pemanfaatan media pembelajaran bahasa Arab di Madrasah Aliyah Kabupaten Sukoharjo umumnya menggunakan by design untuk media PowerPoint, tetapi untuk media lain lebih menggunakan by utilization. Hal ini tidak terlepas dari pertimbangan pragmatis dan praktik dalam mencari yang lebih mudah serta praktis dalam proses pembuatannya. Di samping itu, juga ada pertimbangan faktor kemampuan guru dalam mengembangkan media selain PowerPoint yang umumnya belum dimiliki secara baik. Sebenarnya sudah ada beberapa kali pelatihan atau workshop yang diikuti oleh guru bahasa Arab. Akan tetapi, seringkali kegiatan tersebut kurang optimal dan tidak memberikan pendampingan sampai guru benar-benar dapat menghasilkan produk media pembelajaran yang sesuai dengan kebutuhan kurikulum.

Dalam pengembangan media pembelajaran bahasa Arab menggunakan proses by utilization, sebenarnya terdapat kendala. Di antara kendala yang dihadapi adalah minimnya bahan-bahan online maupun off-line yang sesuai dengan kurikulum pembelajaran di Madrasah Aliyah. Dalam hal ini, bahan-bahan yang sudah ada umumnya lebih sesuai untuk kebutuhan pembelajaran bahasa Arab pada level ibtidaiyyah. Misalnya game-game bahasa Arab seperti "Syajarat al-hurüf", atau materi yang dikembangkan oleh arabindo, dan lain-lain.

Khusus untuk pemanfaatan TIK dalam pengembangan pembelajaran on-line atau e-learning, masih belum digunakan. Yang saat ini sudah ada yang menggunakan baru sebatas mengakses program pembelajaran on-line untuk tugas pembelajaran. Artinya, pemanfaatannya lebih untuk pengembangan dan dilakukan di luar proses pembelajaran, bukan untuk membantu atau 
menggantikan proses pembelajaran. Dalam hal ini, jika melihat pada teori e-learning, maka sebenarnya terbuka peluang untuk pengembangan pembelajaran dengan memanfaatkan TIK seperti menggunakan Learning Management System (LMS), Edmodo, Google Classroom, atau programprogram sejenisnya (Abd. Rozak \& Albantani, 2018). Pemanfaatan website madrasah untuk mendukung proses pembelajaran bahasa Arab juga belum dilakukan.

Proses pemilihan media tersebut jika dikaitkan dengan pendapat Azhar Arsyad (2003) tentang hal-hal yang harus dipertimbangan dalam memilih sebuah media, maka guru telah memilih media dengan kriteria; (a) sesuai dengan tujuan yang akan dicapai, (b) tepat untuk mendukung isi pelajaran yang sifatnya fakta, konsep, prinsip, atau generalisasi, (c) praktis, luwes, dan bertahan, (d) guru terampil menggunakannya, (e) pengelompokan sasaran, dan (f) mutu teknis. Pemilihan media yang digunakan umumnya juga sudah mempertimbangkan aspek tujuan kebahasaan yang jelas, sesuai dengan tingkatan usia siswa, dan membatasi tujuan pembelajaran yang sesuai medianya. Hal ini disebutkan Imam Makruf (2009).

\section{Proses Pemanfaatan Media dan Sumber Belajar Berbasis TIK}

Berdasarkan data yang diperoleh, bahwa proses pemanfaatan media dan sumber belajar bahasa Arab di Madrasah Aliyah di Kabupaten Sukoharjo secara umum memiliki kesamaankesamaan. Di antara kesamaannya adalah, para guru bahasa Arab menggunakan media LCD dalam pembelajaran di kelas dengan orientasi penyampaian materi seperti teks hiwär, teks qiräăh, materi qawā'id, dan penyajian gambar-gambar atau video yang digunakan untuk pembelajaran kalam. Untuk media berupa laboratorium bahasa, pemanfaatan yang paling banyak adalah untuk pembelajaran maharah kalam dengan memanfaatkan bahan ajar yang sudah dikemas dalam file-file mp3 atau video. Di samping itu juga dimanfaatkan untuk muhadatsah langsung dengan guru dan untuk tes kemampuan bahasa Arab.

Dalam konteks teori, penggunaan video dalam pembelajaran dipandang cukup baik. Mark Anderson berkata bahwa video adalah teks baru (Prensky, 2010). Disebut teks baru karena video memenuhi fungsi sebuah teks mulai dari fungsi informatif sampai iteratif dan bahkan fungsi tersebut dimaksimalkan dengan keberadaan elemen audio visual yang menjembatani pemahaman akan materi yang disajikan. Walaupun sudah terbukti bahwa video mampu memberikan dampak positif yang signifikan dalam pembelajaran, permasalahan yang harus diperhatikan adalah pemilihan konten video yang tepat. Guna mengatasi permasalahan pemilihan konten video yang tepat, pengajar bisa menempuh salah satu dari dua cara yaitu membuat video sendiri atau mengunduh video dari situs penyedia layanan video streaming.

Diliihat dari frekuensi pemanfaatannya, media presentasi powerpoint dengan LCD paling sering digunakan guru bahasa Arab. Meskipun antara satu madrasah dengan lainnya berbeda-beda. Untuk Madrasah Aliyah yang telah memiliki LCD pada semua ruang kelas seperti MA As-Salam, maka frekuensi penggunaan media LCD lebih banyak dibandingkan dengan madrasah lain. Dilihat dari orientasi penggunaan media tersebut, yang lebih banyak adalah untuk membantu guru menyampaikan materi pokok pelajaran bahasa Arab. Sedangkan penggunaan media untuk selingan (ice breaking), pembukaan pelajaran (motivasi), atau untuk pengembangan dan pengayaan materi relative lebih jarang digunakan. Dalam proses pemanfaatan, guru mengombinasikan antara presentasi, tanya jawab (interaktif), praktik, dan diskusi tentang materi yang disajikan. Dengan demikian, media tidak diposisikan sebagai pengganti guru, tetapi sebagai pembantu guru dalam menyampaikan materi.

Khusus madrasah berbasis pondok pesantren seperti As-Salam, dapat memberikan pengalaman belajar lebih kepada para peserta didik menggunakan TIK. Misalnya adanya pemutaran live streaming program-program TV seperti Al-Jazeera, atau berisi film, berita, dan lainnya. Pemutaran siaran on-line tersebut tidak dilaksanakan di dalam kelas, tetapi di ruang atau tempat yang lebih luas untuk disaksikan oleh peserta didik secara lebih banyak. Program seperti ini belum dilakukan di Madrasah Aliyah Negeri atau swasta non pondok pesantren. 


\section{Arabi : Journal of Arabic Studies}

Pemanfaatan media secara umum untuk meningkatkan aktivitas peserta didik dalam pembelajaran. Hal ini penting karena variasi aktivitas pembelajaran dengan berbagai strategi terbukti memberikan pengaruh terhadap keberhasilan belajar. Riset yang dilakukan oleh Seechaliao (2017: 201) menunjukkan bahwa berbagai strategi seperti questions, classroom discussion, self-directed study, inductive and deductive thinking, media or social media, dapat meningkatkan aktivitas dalam belajar dan membuat belajar lebih inovatif.

\section{Hasil Pembelajaran Menggunakan Media dan Sumber Belajar Berbasis TIK}

Dilihat dari hasil pembelajaran yang ada pada kelima madrasah di kabupaten Sukoharjo, sesuai kategorisasinya dapat dikelompokkan menjadi tiga. Pertama hasil pembelajaran bahasa Arab pada madrasah swasta berbasis pondok pesantren atau asrama. Kedua hasil pembelajaran bahasa Arab pada madrasah negeri, dan ketiga hasil pembelajaran bahasa Arab pada madrasah swasta biasa.

Dari ketiga kategori tersebut, pembelajaran bahasa Arab pada madrasah Aliyah berbasis pondok pesantren lebih baik dibandingkan dengan Madrasah Aliyah Negeri dan swasta lainnya. Hal ini dapat dilihat dari prestasi para peserta didiknya dalam berbagai kompetisi bahasa Arab baik di tingkat lokal maupun nasional. Di antara prestasi yang pernah diraih para siswa MA AlMukmin Ngruki adalah, menyabet 4 (empat) piala dalam kejuaraan Arabic Fair yang diselenggarakan UNS tahun 2014, yaitu juara 1 pidato Bahasa Arab, mendongeng, kaligrafi, dan lomba rangking 1 bahasa Arab. Begitu pula saat mengikuti Festival Bahasa Arab dan Seni Islami 2014 yang diselenggarakan Ma'had Ali bin Abi Thalib, Universitas Muhammadiyah Yogyakarta, para siswa dapat menyabet sejumlah piala di antaranya juara 1 dan 2 pidato Bahasa Arab, juara 1 seni kaligrafi, dan juara 1 cerdas cermat Bahasa Arab. MA As-Salam juga memiliki banyak prestasi serupa dalam bidang bahasa Arab. Hal ini tidak ditemukan di MA yang berstatus negeri dan swasta non-asrama atau non-pondok pesantren.

Prestasi tersebut tidak terlepas dari adanya program pembelajaran dan pembinaan bahasa Arab yang baik dengan berbagai media dan sumber belajar yang memadai. Misalnya di pondok pesantren modern As-Salam, diberikan fasilitas media pembelajaran bahasa Arab berbasis on-line, dengan menayangkan live streaming dari siaran Timur Tengah, di samping keberadaan laboratorium bahasa yang memadai. Begitu juga dengan yang ada di MA Al-Mukmin yang memiliki sarana di pondok pesantren meskipun pengelolaannya terintegrasi dengan Madrasah Tsanawiyah atau program pondok lainnya.

Dengan hasil-hasil tersebut dapatlah dikatakan bahwa pemanfaatan media dan sumber belajar sangat penting untuk dikembangkan. Madrasah perlu memiliki berbagai alternatif media dan sumber belajar yang memungkinkan para peserta didik memiliki pengalaman belajar yang lebih bervariatif dan lebih aktif dalam praktik berbahasaa Arab. Interaksi dengan dunia luar, terutama dengan bangsa-bangsa Arab akan lebih mudah dilakukan jika memanfaatkan media internet. Media ini pula yang memberikan materi-materi pembelajaran secara update dan mengikuti perkembangan zaman.

Temuan tersebut menunjukkan bahwa penggunaan teknologi sebagai media pembelajaran juga memiliki pengaruh signifikan dalam meningkatkan capaian hasil belajar peserta didik. Hal ini selaras dengan temuan riset dari Asubiojo dan Ajayi (2017) di Nigeria bahwa penggunaan ICT dalam pembelajaran terbukti efektif digunakan dalam pembelajaran. Di samping itu, jika dikaitkan dengan aspek-aspek yang mempengaruhi kemampuan berbahasa Arab peserta didik, pengalaman menyimak penutur asli (nathiq ashli) dari berbagai media on-line juga mempengaruhi kepercayaan diri peserta didik. Kepercayaan diri yang merupakan faktor internal inilah yang menurut penelitian Haron dkk (2016) lebih memberikan pengaruh terhadap kemampuan menjadi penutur Arab yang baik. 


\section{Simpulan}

Berdasarkan hasil analisis dan pembahasan data-data tersebut, dapat ditarik kesimpulan bahwa media dan sumber belajar bahasa Arab berbasis TIK yang digunakan di Madrasah Aliyah Kabupaten Sukoharjo adalah bahan presentasi PowerPoint dengan LCD, laboratorium bahasa, dan bahan audio visual seperti video atau media audio berbentuk mp3. Sedangkan sumber belajar yang digunakan umumnya adalah file-file dalam bentuk pdf yang sudah diunduh. Untuk bahan-bahan yang masih on-line hanya beberapa guru yang menggunakan dengan frekuensi penggunaan yang jarang. Hal ini salah satu faktor penyebabnya adalah kemampuan guru dalam bidang pengembangan media pembelajaran yang kurang memadai. Di samping itu juga ketersediaan sarana prasarana di madrasah yang kurang mencukupi.

Proses pemilihan/pengembangan media dan sumber belajar bahasa Arab berbasis TIK di Madrasah Aliyah Kabupaten Sukoharjo diklasifikasi menjadi dua, yaitu media by design dan media by utilization. Media by design adalah PowerPoint yang berbentuk teks yang dipadukan dengan gambar atau video dengan animasinya. Sedangkan media by utilization umumnya berupa video, game, atau bahan-bahan on-line yang dianggap relevan. Dalam proses pengembangan media by design pula tidak semua bahan dibuat sendiri, tetapi sebagian diambil dari bahan-bahan yang sudah ada dan dikembangkan oleh orang lain melalui media on-line maupun off-line. Dalam hal ini, MGMP juga belum menghasilkan produk-produk media pembelajaran yang dibutuhkan dalam pembelajaran.Proses pemanfaatan media dan sumber belajar bahasa Arab berbasis TIK umumnya dilakukan dalam menyampaikan materi pembelajaran atau kegiatan inti. Sedangkan pada kegiatan pendahuluan (motivasi) atau kegiatan penutup (evaluasi) belum banyak dilakukan. Pemanfaatan lain juga dilakukan untuk pengayaan dalam bentuk penugasan untuk browsing materi yang dibahas di luar jam pembelajaran. Dalam proses pemanfaatan, guru mengombinasikan antara presentasi, tanya jawab (interaktif), praktik, dan diskusi tentang materi yang disajikan.

Media dan sumber belajar bahasa Arab berbasis TIK terutama yang memanfaatkan media online untuk mengakses năthiq ash $\bar{i}$ dalam pembelajaran, memiliki dampak yang positif terhadap peningkatan motivasi dan kepercayaan diri peserta didik dalam berbahasa Arab dengan baik. Hal ini dibuktikan dengan adanya prestasi kompetisi bahasa Arab para peserta didik yang berasal dari madrasah berbasis pondok pesantren yang menggunakan TIK untuk menampilkan materi-materi dari năthiq ashli lebih unggul dibandingkan dengan madrasah negeri dan swasta non-pesantren atau non-asrama. Dengan demikian, solusi yang dapat diberikan di antaranya adalah dengan memberikan peningkatan pada kompetensi guru bahasa Arab dalam bidang TIK, penambahan sarana-prasarana terkait dengan pengembangan dan pemanfaatan TIK sebagai media dan sumber pembelajaran bahasa Arab, serta kemampuan berbahasa Arab aktif agar lebih memotivasi peserta didik.[]

\section{Daftar Rujukan}

Abd. Rozak., \& A.M. Albantani. 2018. "Desain Perkuliahan Bahasa Arab Melalui Google Classroom ", Arabiyat : Jurnal Pendidikan Bahasa Arab dan Kebahasaaraban, Vol. 5, No. 1.

Albantani, A.M., \& A. Madkur. 2019. "Teaching Arabic in the era of Industrial Revolution 4.0 in Indonesia: Challenges and opportunities", ASEAN Journal of Community Engagement, Vol. 3, No. 2.

Arsyad, Azhar. 2003. Bahasa Arab dan Metode Pengajarannya. Yogyakarta: Pustaka Pelajar.

Arsyad, Azhar. 2003. Media Pembelajaran. Jakarta: PT. RajaGrafindo Persada.

Asubiojo, Raphael Ojo., \& James Adedeji Ajayi. 2017. "The Role of Information and Communication Technology in Enhancing Instructional Effectiveness in Teachers' Education in Nigeria", KIU Journal of Social Sciences, Vol. 3, No. 2. 


\section{Arabi : Journal of Arabic Studies}

Banditvilai, Choosri. 2016. "Enhancing Students' Language Skills through Blended Learning", Electronic Journal of e-Learning, Vol. 14, No. 3.

Bin Samah, R., F. Puteh-Behak, N. S. Mat Saad, S.M. Ali, R. Darmi, \& H. Harun. 2016. "Effective Methods in Learning Arabic Language as a Foreign Language", Mediterranean Journal of Social Sciences, Vol. 7, No. 3.

Gerlach, V.G., \& D.P. Ely. 1971. Teaching and Media, A Systematic Approach. Englewood Cliffs: Prentice-Hall, Inc.

Haron, Sueraya Che., Ismaiel Hassanien Ahmed, Arifin Mamat, Wan Rusli Wan Ahmad, Fouad Mahmoud M. Rawash. 2016. "Challenges in Learning to Speak Arabic", Journal of Education and Practice, Vol. 7, No. 24.

Heinich, Robert., dkk. 2005. Instructional Technology and Media for Learning. New Jersey: Pearson Prentice Hall.

Isykarima. 2017. "SEKDA Karanganyar Resmikan Pakel sebagai Desa Wisata Bahasa", dari http://isykarima.com/sekda-karanganyar-resmikan-pakel-sebagai-desa-wisata-bahasa/ diakses pada 20 Januari 2020.

Makruf, Imam. 2009. Strategi Pembelajaran Bahasa Arab Aktif. Semarang: Need's Press.

Makruf, Imam., dkk. 2010. "Strategi Pengembangan Kompetensi Mengajar PPL Jurusan Tarbiyah STAIN Surakarta (Refleksi Akademis atas Pelaksanaan PPL Mahasiswa Jurusan Tarbiyah STAIN Surakarta Prodi PBA dan Prodi PAI Tahun Akademik 2009-2010)", Laporan Penelitian, P3M STAIN Surakarta.

Munir. 2008. Kurikulum Berbasis Teknologi Informasi dan Komunikasi. Bandung: Alfabeta.

Nuraini, Attia. 2009. "Penerapan Model Pembelajaran Blended E-Learning dan Proses Perkuliahan", Laporan Penelitian, Bandung: UPI.

Ritonga, Mahyudin., dkk. 2016. "Pembelajaran Bahasa Arab berbasis Teknologi Informasi dan Komunikasi di Kota Padang", Arabiyat: Jurnal Pendidikan Bahasa Arab dan Kebahasaaraban, Vol. 3, No. 1.

Salim, Muhammad Ahmad. 1987. al-Wasā'il at-Ta'Timiyyah fi Ta'Tim al-'Arabiyyah, Lughah Ajnabiyyah. Li ad-Daurah at-Tarbawiyyah al-Mukatstsafah. Jakarta: LIPIA.

Seechaliao, Thapanee. 2017. "Instructional Strategies to Support Creativity and Innovation in Education", Journal of Education and Learning, Vol. 6, No. 4.

Seels, Barbara B., \& Rita C. Richey. 1994. Teknologi Pembelajaran, Definisi dan Kawasannya, Penterj: Dewi S. Prawiradilaga, dkk. Jakarta: Unit Percetakan Universitas Negeri Jakarta.

Sugiyono. 2017. Metode Penelitian Kuantitatif, Kualitatif dan R\&D. Bandung: Alfabeta.

Suwito. 2009. "Pembelajaran Bahasa Arab dengan On-line Self Access Learning”, Insania, Vol. 14, No. 1.

Wardhani, Evi Rakhmawati. 2010. "Pembelajaran bahasa Arab di SMA Negeri Se- Kota Malang", dari http://karya-ilmiah.um.ac.id/index.php/sastra-arab/article/view/5445 diakses pada 20 Januari 2020. 